EESTI NSV TEADUSTE AKADEEMIA TOIMETISED 1955. IV kd., nr. 1 ИЗВЕСТИЯ АКАДЕМИИ НАУК ЭСТОНСКОП ССР 1955. ТоМ IV, № 1

\title{
INGLISE-SAKSA IMPERIALISTLIKUST KOKKULEPPEST BALTI MERE JA BALTIMAADE KUSIMUSES (1935. a.)
}

\author{
M. PESTI
}

Olemaailmne majanduskriis aastail $1929-1933$ suurendas kodanliku Eesti majanduslikku ja poliitilist sõltuvust imperialistlikest riikidest. Seoses Hitleri võimuletulekuga Saksamaal ning Saksa imperialismi avalikult ekspansionistliku poliitika uuestialustamisega teravnes ka võitlus Baltimaade turgude pärast. Aastail $1933-1934$ olid Balti riigid Briti ja Saksa monopolide vahelise ägeda konkurentsivõitluse areeniks.

Selles vôitluses oli Inglismaal kindel ülekaal. Selle ülekaalu säilitas Inglismaa seetõttu, et ta ostis märksa suurema osa Balti riikide ekspordist kui Saksamaa. Samal ájal kui Eesti import Inglismaalt ja Saksamaalt oli peaaegu võrdne, eksporteeris ta 1933. aastal Inglismaale peaaegu kaks korda rohkem kui Saksamaale.

Oma esikoha säilitamiseks Balti riikide väliskaubanduses kasutas Inglismaa aastail $1933-1934$ ka poliitilist survet. Silmas pidades mõningaid Saksa kaubandusliku ekspansiooni tunnuseid Eestis, hoiatas Inglise välisministeeriumi põhjamaade osakonna juhataja Collier Eesti esindajat 1933. aasta septembris: „Saksa majanduslik lähenemine Balti riikidele ükskõik mis sildi all ei ole Britile mitte vastuvõetav" 1 .

Vastuseks saksa monopolide tugevnevale ekspansioonile teostas Suurbritannia Balti riikidele võimsa ,ekspordirünnaku”, mida Eesti kaubandustööstusringkondade häälekandja „Päevaleht” hindas koguni kui püüet „laiendada Ottavas loodud majandussüsteemi Skandinaavia ja Balti riikidele" 2 .

Tänu oma otsustavale mõjule Baltimaades läks Inglismaal 1934. aastal korda sõlmida talle vägagi soodsad kaubalepingud Eesti, Läti ja Leeduga. Need lepingud, mis olid sõlmitud tähtajaga $2 \frac{1}{2}$ kuni 3 aastat, andsid Inglismaale suuri eeliseid tollimäärade, inglise kaupade kohustusliku ostmise, kaupade veol inglise tonnaaži kasutamise jne. suhtes ${ }^{3}$.

Nende abinõude tulemusena säilitas Suurbritannia saksa monopolide tugevdatud pealetungile vaatamata oma endise seisundi Balti riikide turgudel.

1 Londonis asuva Eesti saatkonna ettekanne välisministeeriumile 19. septembrist 1933. ENSV ORKA, fond 957, nimistu 13, toimik 743, leht 49.

2 "Päevaleht” nr. 111, 24. apr. 1934.

3 «Правда» № 251 от 11 сентября 1934 г. Корреспонденция «Англо-германская борьба за рынки Прибалтики». 
Uhtlasi ei lasknud Suurbritannia mööda ühtki juhust, et rõhutada seda tähtsust, mida ta omistas Balti merele ja Balti riikidele sõjalis-strateegilises suhtes. 1934. aasta kevadel korraldas Inglise admiraliteet Balti merel suure mereväedemonstratsiooni. Pärast Briti laevastiku manöövreid Šotimaa ranniku lähedal suundus suur rühm laevu - nende hulgas lahingulaevad, ristlejad ja miinilaevad - Balti merele. Oks ristlejate flotill külastas kõigi Balti riikide sadamaid ${ }^{4}$.

Kuid äge konkurentsivõitlus kahe imperialistliku riigi vahel majandusliku ja sõjalis-poliitilise ülevõimu pärast Balti mere idakaldal ei kõrvaldanud hoopiski vastastikuseid lähenemiskatseid kompromissi saavutamise eesmärgil. Sääraste otsingute aluseks olid Nõukogude-vastased taotlused, mis olid võrdselt omased nii Saksa kui ka Inglise imperialistidele, ning imperialistide püüd mõjusfääride ja kapitalimahutuse sfääride jaotamiseks. Mis puutub Baltimaade rahvaste endi tahtesse, kes taotlesid rahu ja sõprust Nõukogude Liiduga, siis seda ei võtnud imperialistlikud sõjaōhutajad mingil määral arvesse.

Juba 1934. aastal jõudsid Eesti valitsuse juhtideni teated selle kohta, et mõjukad inglise ringkonnad on hitlerlikule Saksamaale üldise lähenemise taustal nõus leppima Saksa mõju tunduva tugevnemisega Balti mere idarannikul. Peale tuntud Hitleri-sõbraliku „Clivedeni kliki” tegelesid Balti, eriti aga Klaipeda (Meemeli) asjadesse vahelesegamisest loobumise propageerimisega lord Beaverbrooki trusti ajalehed - „Evening Standard" jt. ${ }^{5}$

Sama aasta oktoobris ilmusid inglise ajalehtede veergudele teated Saksa plaanidest Taani väinade kindlustamise ja "neutraliseerimise” kohta. Seejuures märgiti, et Saksamaa, kelle käsutuses oli Kieli kanal, poleks säärase „neutraliseerimise” läbi midagi kaotanud. Ajaleht ,,Sunday Referee" kirjutas, et selle plaani teostamine ,isoleeriks NSV Liidu ning looks Saksamaale Balti meres valitseva seisundi. Veelgi enam, see tõmbaks Balti riigid automaatselt ühisrindesse Saksamaaga" 6 .

„Sunday Referee" vihjas samuti asjaolule, et just selle plaani teostamine oli kurikuulsa hitlerliku diplomaadi von Papeni poolt 1934. aasta oktoobris teostatud Stokholmi-sõidu tõeliseks eesmärgiks.

Nagu näitab Eesti välisministeeriumi kirjavahetus saatkondadega, jälgis Eesti diplomaatia teraselt sääraseid plaane ja samme ning valitsus võttis vastavaid teateid arvesse riigi välispoliitilise kursi kindlaksmääramisel. Rahvusvahelistes asjades kõige vilunumad valitsevate ringkondade esindajad taipasid kiiresti mitmesuguste kuulduste mõtet. Nii kirjutas saadik Kaunases Leppik 1935. aasta algul, rääkides Saksa-Leedu konfliktist Klaipeda piirkonna pärast: „Briti näib ikka enam toetavat autonoomiat Saksa interpretatsiooni kohaselt ... Inglismaa ... näeks vast praegu rahuldusega Saksa diplomaatia kõvenemist teatud määral Balti riikides ja selle kaudu SSSR vastase frondi osalist kindlustamist" ?.

1935. aasta veebruaris-märtsis hakkasid üha visamalt levima kuuldused kas alles ettevalmistatavast vōi juba teoks saanud kokkuleppest Inglismaa ja Saksamaa vahel Balti küsimuses. Sellest tegi juttu isegi Eesti välisminister Seljamaa ühes oma ettekandes riigivanemale. Minister; kes harilikult kandis riigivanemale ette ainult niisugustest asjadest, milles ta ise ei kahelnud, jutustab selles ettekandes instruktsioonidest, mida oli Berliinis săanud Eesti 'sakslaste „füürer” Lutz seoses Eesti üleminekuga Saksamaa mõjusfääri. Seljamaa sõnade järgi öeldi Berliinis Lutzile, et 1935.

4 «Правда» № 163 от 15 июня 1934 г.

5 Vt. näit. "Evening Standardi” juhtkiri 1. maist 1934.

6 Tsiteeritud „Pravda” järgi (nr. 300, 30. okt. 1934).

7 Kaunases asuva Eesti saatkonna tegevuse kolme kuu aruanne, oktoober - detsember 1934. ENSV ORKA, f. 957, nim. 14, toim. 6, 1. 231. 
aasta algul on Inglismaa ja Saksamaa kokku leppinud mõjusfääride ümberjaotamise küsimuses. Selle kokkuleppe alusel minevat Soome, Eesti ja Läti Saksamaa mõjusfääri ${ }^{8}$.

Endastmōistetavalt ei saa meie kasutuses olla täiesti usaldusväärseid andmeid Inglise-Saksa läbirääkimiste või kokkuleppe kohta Baltimaade küsimuses 1935. aasta algul, kuid mõningad uued momendid Inglise diplomaatia tegevuses Baltimaadel ja Poolas viivad mõttele sellest, et tähendatud ajal ołi käimas ettevalmistustöö, tee tasandamine Inglise-Saksa kokkuleppeks Baltimaade küsimuses. Missugused on need uued momendid?

Selleks on eelkõige Inglise ja Ameerika diplomaatia uus ,hoolitsuse", puhang, et kindlustada Balti riikide sõltumatust ... Nõukogude Liidust. 1935. aasta esimestel kuudel, kui Saksamaa arendas oma agressiivset tegevust Leedu ja teiste Balti riikide vastu, NSV Liit aga astus väsimatult välja nende riikide kaitseks, ilmutasid Inglise diplomaadid mitmetes pealinnades äkki rahutust selle üle, kas ei ähvarda Balti riike oht idast! Nii näiteks tundis Briti Berliini saatkonna nõunik Newton jutuajamisel Eesti saatkonna nõunikuga erakordset huvi selle vastu, kuidas Eestis hinnatakse olukorda Ida-Euroopas riigi julgeoleku seisukohalt, ning soovitas mitte unustada, et Eesti on ,esimeses järjekorras eksponeeritud mitte Saksa, vaid Vene hädaohule" 9 . Eesti valitsejate täielikust nõusolekust selle provokatsioonilise avaldusega annab tunnistust selle kirja äärele ministri poolt kirjutatud resolutsioon: „Oige!"

Nõukogude-vastasele ässitustööle lõi kaasa ka Ameerika diplomaatia. Nii külastas 24: augustil 1935. aastal Eesti saadikut Moskvas Ameerika Uhendriikide saatkonna nõunik Wiley ning teatas saadikule Ameerika valitsuse eelseisvast ,protestist" Nõukogude valitsuse ees Moskvas toimunud Kommunistliku Internatsionaali VII kongressi puhul. Nagu kirjutas Eesti saadik Tofer oma ettekandes, palus ameerika diplomaat teda läbi lugeda Ameerika Ohendriikide noodi, mille Ameerika suursaadik kavatses üle anda NSV Liidu välisasjade rahvakomissarile, ja välja kirjutada „,iseloomustavamad kohad" sellest dokumendist. Ässitades Eestit analoogilisele väljaastumisele, teatas Wiley, et, ,meie (s. o. Ameerika Uhendriigid M. P.) võiksime minna ka siinse esinduse likvideerimiseni" 10

Ameerika diplomaadi demaršil polnud otseseid tagajärgi: Eesti valitsus ei söandanud veel astuda säärast jultunud sammu, nagu seda oli Ameerika Uhendriikide ,protest" Nõukogude valitsuse ees; kuid ameerika imperialistide häbematu väljaastumine täitis Eesti reaktsiooniliste valitsejate südameid rõõmuga ning õhutas neid oma Nõukogude-vastaseid intriige kõvendama.

Meid huvitab sellega seoses eelkõige asjaolu, et Inglismaa ja Ameerika Uhendriikide diplomaatide säärased provokatsioonid sagenesid just 1935. aasta kevadel ja suvel — perioodil, mil vormistati Inglise-Saksa kokkulepet Baltimaade küsimuses. Veidi varem, aastail $1933-1934$, Inglise diplomaatia teatud määral isegi hóiatas Eesti valitsevaid ringkondi tõelise ohu eest, mis Eestit ähvardas hitlerliku Saksamaa poolt.

Teiseks uueks momendiks oli Inglismaa tugev surve Leedule, et saavutada viimaselt järeleandmisi Saksa-Leedu tüliküsimuses Klaipeda pärast, samuti ka Inglise diplomaatia kaasabi Eesti püüetele Leedu ja Poola

s Välisministri ettekanne riigivanemiale, dateeritud „veebr. 1935. a," ENSV ORKA, f. 957 , nim. 14 , toim. $181,1,2-7$.

9 Berliinis asuva Eesti saatkonna kiri välisministeeriumile 7. märtsist 1935. ENSV ORKA, f. 957 , nim. 14, toim. 35, 1. 35-36.

10 Moskvas asuva Eesti saadiku ettekanne 10. oktoobrist 1935. ENSV ORKA, f. 957, nim. 14, toim. 171, 1. 25-29. 
„lepitamiseks”. Nii üks kui teine sepitsus oleks õnnestumise korral hõlbustanud fašistliku Saksamaa agressiivseid samme Baltikumis.

Inglise survest Leedule annavad tunnistust paljud diplomaatilise kirjavahetuse dokumendid. Selles suhtes on näiteks huvitav Londonis asuva Eesti saadiku ettekanne 3. maist 1935. Selles kirjas teatab saadik Schmidt, et Briti välisministeeriumi põhjamaade osakonna juhataja Collier võttis vastu kõigi Balti riikide saadikud ning „Leedu saadikuga on $\mathrm{Mr}$. C. veel kõnelnud Saksa juurdetõmbamise vajadusest Ida lepete süsteemi nonagressiooni lepingu näol Saksa ja Balti riikide vahel ..." ${ }^{11}$.

Teatavasti kuulutas Hitler 1935. aasta märtsis, et ta tühistab Versailles' lepingu sõjalised sätted; algas Saksamaa avalik ümberrelvastumine uueks sõjaks. Suurbritannia valitsus avaldas sel puhul oma vaikse ,protesti" ning ... saatis oma välisministri John Simoni Berliini, et sondeerida pinda kokkuleppeks Hitleriga. Kui Simoni poolt Berliinis 24,-26. märtsini 1935. a. peetud läbirääkimiste üle otsustada aruande järgi, mille ta esitas alamkojas, siis võiks mõelda, et nende läbirääkimiste käigus inglased ainult kuulasid, kuidas Hitler loetles kõiki omá nõudmisi. Tuleb aga arvata, et tegelikult võtsid inglased hoopis aktiivsemalt osa Briti ja Saksa imperialismi vahelise kokkuleppe sobitamisest.

Berliini läbirääkimised Hitleri ja Simoni vahel tähistasid muuhulgas ka teatavat muutumise etappi Inglise suhtumises Balti riikidesse. Just pärast neid läbirääkimisi ilmusid inglise tegelaste poolt Baltimaade olukorra kohta tehtud avaldustesse teatud tüdimuse ja kannatamatuse toonid. Iseloomulik näide selle kohta leidub Londoni Eesti saatkonna ettekandes 9. aprillist 1935. aastal. Selles dokumendis märgitakse eelkõige, et „meie laenupaberid Berliini kohtamise järel hakkasid Londonis langema ... Uks Citý ekspertidest ütles mulle, et tema arvates langus on tingitud ainult poliitilisest olukorrast" ${ }^{2}$. Samas ettekandes öeldakse, et „kisa Klaipeda küsimuse ja Idapakti ümber" on tekitanud Londonis mulje, et Balti riigid asetsevad ,hädaohtlikus tsoonis”. Ettekande autorid toovad ära ka ajalehe „Manchester Guardian” sõnad (27. märtsi numbrist), et ,üldine muutus kogu Ida-Euroopa olukorras on vältimatu ning see hõlmab ka Meemeli statuuti nagu paljusid teisigi asju" ${ }^{13}$.

Huvitav on märkida, et saatkonna ainsaks kommentaariks selle juurde oli soov, et Eesti väärtpaberite kursi edasise languse vältimiseks ,kaoks närveeriv kisa Idapakti ümber", s, o. et Ida-Euroopa kollektiivse julgeoleku plaan maha maetaks.

Kohtumisel Simoniga nõudsid sakslased esmakordselt endile õigust ehitada Saksa sõjalaevastik $35 \%$ suuruseni Suurbritannia laevastikust. Uhtlasi teatas Saksamaa oma kavatsusest hakata ehitama ,mōningaid väikesi" allveelaevu. Inglismaal saadi hitlerlaste nende avalduste tähendusest kohe õigesti aru. Ajaleht „Manchester Guardian” märkis, et kui Saksamaa tõesti saab tonnaaži $35 \%$ ulatuses Briti sõjalaevastiku omast, siis „on tasakaal Balti merel kohe häiritud ... Põhilise pöörde ohus on praegu ka kogu Balti riikide probleem .... Kui Saksamaa saavutab ülevõimu Balti merel, siis on kõik Balti riigid otseses ohus. Läti ja Eesti pealinnad Riia ja Tallinn on sadamad ning nende üle võivad Saksa laevade kahurid kergesti valitseda" 14 .

Hitlerlased ei püüdnudki varjata oma kavatsusi Balti mere basseini suhtes. Olles teadlikud Ameerika ja Inglise imperialistide südamesoovist

11 ENSV ORKA, f. 957, nim. 14, toim. 170, 1. 3.

12 ENSV ORKA, f. 957, nim. 14, toim. 20, 1. 15.

$13 \mathrm{Sea}$ ls a m a s.

14 "The Manchester Guardian", April 29, 1935. 
viia Saksamaa kokkupõrkele NSV Liiduga, spekuleerisid fašistlikud ninamehed sellele ning vestlustes inglise ja ameerika tegelastega arendasid nad laialt oma agressiivseid plaane just selles suunas, mis viis Leningradi lähistele. Fašistlike ninameeste säärased kinnitused on leidnud mõningat kajastust isegi juhtivate kodanlike diplomaatide trükis avaldatud memuaarides. Nii jutustab Ameerika Uhendriikide suursaadik Berliinis W. Dodd oma „päevikus” Inglise suursaadiku Phipps'i jutuajamisest Hitleriga, mis leidis aset 1935. aasta aprillis ning milles Hitler põhjendas oma nõudlusi sõjalaevastiku suhtes just sellega, et ,meil peab olema sõjalaevu kogu Balti merel" ${ }^{15}$. Veelgi avameelsemalt rääkis Saksamaa agressiivsetest plaanidest hitlerlik välisminister von Neurath. Jutuajamisel Dodd'iga 6. juulil 1935 ütles ta: „See piirkond (s. o. Baltikum - M. P.) peab olema meie kontrolli all, et Venemaad ookeanist eemal hoida" ${ }^{6}$. Ning arendades agressiivseid kavatsusi, „tõestas" von Neurath Ameerika Ohendriikide suursaadikule kohe sealsamas, et „Jaapan peab valitsema KaugIda ning hõivama Vladivostoki. Saksamaa peab valitsema Euroopat, kõigepealt a ga B a ltikumi..." 17 (minu sõrendus - M. P.).

Samal ajal kuuldus Inglismaalt hääli selle kohta, et Suurbritannia pole Baltikumist üldse huvitatud. Ajaleht „Daily Telegraph” kirjutas 1935. aasta 15. mai numbris otseselt, et regionaalselt pole Inglismaa Kirde-Euroopast huvitatud, ning Eesti saadik Londonis kurtis oma ettekandes 20. juunist: „... on siin nüüd mitmel puhul korduvalt kinnitatud, nii sõnas kui kirjas, et julgeoleku tagatiste alal Briti Balti riikide suhtes ei saa oma peale võtta mingeid kohustusi" ${ }^{18}$. Ajaleht „Manchester Guardian” aga kirjutas 7. mail täiesti avalikult ja rahulikult: „Kuna Saksamaa mereväeprogramm annab talle tõenäoliselt kontrolli Balti mere üle, lähevad kõik Balti riigid Saksa välispoliitika mõjusfääri" 19 .

Rööbiti avaliku arvamuse ettevalmistamisega Balti mere basseinist loobumiseks tegid Inglise imperialistid Saksamaaga peetud läbirääkimiste ajajärgul kõik, et kergendada hitlerlastele nende ülesannet Baltimaades. Peamiseks takistuseks saksa agressioonile selles suunas oli tol ajal Leedu vastupanu, kelle võitlust oma territooriumi puutumatuse eest toetas NSV Liit. Leedu valitsus keeldus täitmast Hitleri ülbeid nõudmisi Klaipeda küsimuses, millede vastuvõtmine oleks lõppkokkuvõttes tähendanud Leedu muutumist fašistliku Saksamaa vasalliks, ning võttis tarvitusele mõningaid abinõusid Klaipedas tegutseva hitlerliku agentuuri õõnestustöö ohjeldamiseks. 1935. aasta kevadel toimus Kaunases Klaipeda piirkonda saadetud hitlerlike diversantide suur protsess. Mitte ainult Saksa, vaid ka Inglise imperialistid kasutasid seda protsessi ettekäändena Leedu valitsusele toore surve avaldamiseks. Rida inglise ajalehti ning paljud parlamendiliikmed vōtsid "Meemeli rahva jalgade alla tallatud öiguste" kaitsja poosi. Briti valitsus avaldas Klaipeda statuudi signataarina survet Leedule, taotledes temalt suuremat järeleandlikkust konfliktis Saksamaaga. Asi läks nii kaugele, et välisminister Simon teatas 29. mail alamkojas avalikult, et Inglise valitsus ei ole rahul Leedu vastusega signataarriikide noodile, ja lisas, et Inglismaa võtab enesele initsiatiivi uue signataarriikide noodi

15 Ambassador Dodd's Diary 1933-1938, New York, 1941, p. 252-253: "we must have warships all over the Baltic Sea".

16 S e a ls a m a s, p. 256: "We must control that area to keep Russia off the ocean".

17 Sealsamas, p. 257: "Japan must dominate the Far East and capture Vladivostok. Germany must dominate Europe, but first the Baltic

18 ENSV ORKA, f. 957, nim. 14, toim. 10, 1. 53.

19 S a Is a m a S. 
saatmiseks, milles kategoorilisemalt nõutakse „olukorra normaliseerimist" Klaipeda piirkonnas ${ }^{20}$.

Samal ajal said Inglise valitsevad ringkonnad küllalt selgelt ja õigesti aru, mida tähendavad Saksa nõudlused Klaipeda piirkonna suhtes. Nii rõhutas konservatiivne ajaleht „Morning Post” 25. mail 1935. aastal, et Meemeli piirkond ei paku Saksamaale mingit majanduslikku huvi ja et Meemel on Saksamaale vajalik „Drang nach Osten” idee realiseerimiseks ${ }^{21}$.

1935. aasta alguses tekkima hakanud sobing Suurbritannia ja Saksamaa vahel ülevõimu küsimuses Balti merel ning selle idarannikul vormistati lōplikult Inglise-Saksa mereväe-kokkuleppes, mis sõlmiti 18. juunil 1935. aastal. See kokkulepe, nagu märgiti nõukogude kirjanduses kohe pärast selle allakirjutamist, oli ,uueks teguriks, mis oli arvestatud selleks, et hõlbustada saksa fašismi edasist relvastumist ning ette valmistada uut sõda, esmajoones Idas, s. o. Nõukogude Liidu vastu" 22 .

Mereväe-kokkuleppes nõustus Inglismaa rahuldama Hitleri peamist nõudmist, - et Saksamaale antaks õigus ehitada sõjalaevastik, mille suurus oleks $35 \%$ Briti impeeriumi merejõududest. Sellega sanktsioneeris Inglismaa Versailles' rahulepingu viienda osa jämeda rikkumise Saksamaa poolt ning lõhkus endiste liitlasriikide - Inglismaa, Prantsusmaa ja Itaalia - tuntud „Stresa rinde”. Inglise-Saksa separaatse kokkuleppe sốlmimine mererelvastuse küsimuses oli rängaks hoobiks Euroopa kollektiivse julgeoleku süsteemi organiseerimise püüetele, tähendades Hitleri diplomaatia suurt edu tema püüetes mitte lasta luua riikide ühisrinnet Saksa agressiooni vastu.

Ôldsuhte 35:100 kõrval määrati kokkuleppes kindlaks Saksamaale veelgi soodsam suhe allveelaevade osas. Viimaste suhtes kindlustati Saksamaale õigus omada Briti impeeriumi allveelaevade kogutonnaažiga võrdset tonnaaži. Tõsi küll, eriolukorrad välja arvatud, nõustus Saksamaa allveelaevade osas mitte ületama $45 \%$ Briti allveelaevastiku tonnaažist, kuid Saksa valitsus võis ,juhul, kui tekib eriline situatsioon, mis tema arvates teeb Saksamaale vajalikuks kasutada tema õigust" ületada eespool nimetatud limiit, informeerides sellest Inglise valitsust, et koos viimasega arutada situatsiooni, enne kui Saksa valitsus asub oma „õiguse” teostamisele.

Kokkulepe andis Saksamaale võimaluse omả merejõudude tohutuks suurendamiseks. 1935. aastal oli Saksamaal sõjalaevastik kogutonnaažiga $78600 \mathrm{t}$, kuna uue kokkuleppe põhjal võis ta omada laevastikku kogutonnaažiga vähemalt $420600 \mathrm{t}^{23}$. Seega lubas Inglise valitsus Saksamaale suurendada oma sõjalaevastikku rohkem kui viiekordseks. Nagu märgiti rea maade ajakirjanduses, olid Saksamaale sellest ajast praktiliselt avatud piiramatud vỗimalused oma merejõudude suurendamiseks.

Mispärast läks Inglise valitsus sääraste suurte järeleandmisteni hitlerliku Saksamaa ees Briti impeeriumile eluliselt tähtsas merejõudude küsimuses? Nagu on näidatud paljudes selle küsimuse kohta kirjutatud artiklites ja uurimustes, polnud võimalik Inglise-Saksa mereväe-kokkulepet puhtmeresôjalisest seisukohast lähtudes kuidagi Inglismaale soodsaks pidada, vaid vastupidi - see kokkulepe oli Inglismaale äärmiselt ebasoodne. Saksamaa ei andnud oma partnerile mingeid märgatavaid kompensatsioone vastutasuks määratu suurte järeleandmiste eest. Kokkulepe Hitleriga tõi

20 "The Times", May 30, 1935.

21 "The Morning Post", May 25, 1935.

22 Л. Иванов, Морское соперничество империалистических держав, Соцэкгиз, М.-Л., 1936, стр. 107. Raamatu lisas on avaldatud Inglise-Saksa 1935. aasta mereväe-kokkuleppe täielik tekst.

28 История дипломатии, Том третий, М.-Л., 1945, стр. 547. 
Inglismaale tunduvaid ebameeldivusi ka poliitiliselt: ta tõi kaasa ohu, et Inglismaast võivad eemalduda tema senised liitlased eesotsas Prantsusmaaga. Ometi kiitis inglise imperialistlik kodanlus valitsuse sammu heaks ja toetas seda.

Seda saab seletada ainult siis, kui silmas pidada Inglise ja Ameerika imperialismi kaugeleulatuvaid sõjalis-poliitilisi plaane, eelkõige tema Nõukogude-vastaseid püüdlusi. Inglise imperialismi tähtsaimaks motiiviks Saksamaaga mereväe-kokkuleppe sõlmimisel oli soov suunata Hitleri agressioon itta, NSV Liidu vastu. Sel eesmärgil oli teiste abinõude kôrval hädavajalik anda fašistlikule Saksamaale platsdarme plaanitsetava Nõukogude-vastase sõja kirdepoolses strateegilises suunas - Leningradi ja Minski lähistel. Selleks pidasid Inglise ja Ameerika imperialistid vajalikuks mitte ainult tagada Saksa laevastikule täielik ülevõim Balti merel, vaid ka - mis veelgi tähtsam - lasta Saksamaal kanda kinnitada selle idakaldal, kolmes Balti riigis. Nende väikeste ja looduslike ressursside poolest vaeste maade loovutamine oma mõjusfäärist ei võinud tuua suurt kahju Inglise imperialismile, seda enam, et Saksamaa lubas arvestada Inglismaa majanduslikke huve Eestis ja Lätis. Pärast impeeriumi valduste omavahelisi suhteid reguleeriva tuntud „Ottava süsteemi” loomist võeti Inglismaal koguni kergendustundega vastu mõte Balti riikide põllumajandussaaduste impordi vähenemisest. Igal juhul polnud Balti riikidel Inglise-Ameerika imperialismi jaoks nii suurt väärtust, et selle loovutamist oleks tulnud pidada liiga kõrgeks hinnaks säärase imperialistidele südamelähedase asja eest, nagu seda oli fašistliku Saksamaa oodatud sõjakäik Nõukogude Liidu vastu.

Mõistagi ei saanud Inglise-Saksa mereväe-kokkulepe, nagu igasugune muugi imperialistide vaheline kokkulepe, kaasa tuua Balti mere basseini probleemi püsivat ja lõplikku lahendust. Sellest annab tunnistust fakt, et just aastail 1935 - 1936 võis märgata Skandinaavia turgudel briti ja saksa monopolide konkurentsivõitluse järsku teravnemist. Balti mere idakaldal asetsevatele riikidele aga avas Inglise-Saksa kokkulepe teatud ajavahemikuks selge perspektiivi - muutuda hitlerliku Saksamaa satelliitideks.

Inglise-Saksa mereväe-kokkuleppe Nõukogude-vastasest olemusest annab tunnistust ka asjaolu, et teised imperialistlikud suurriigid, kes unistasid Nõukogude Liidu sissepiiramisest, - Ameerika Ohendriigid ja Jaapan - kiitsid selle kokkuleppe palavalt heaks. Nagu teatas Londoni ajaleht „Times”, väljendasid nii Ameerika Uhendriikide kui ka Jaapani valitsus juba enne Inglise-Saksa kokkuleppe sõlmimist „oma soodsat suhtumist" ${ }^{24}$ sellesse kokkuleppesse.

Kui mitte arvestada saksa fašistlikke ringkondi, siis ei olnud rahvusvahelises avalikus arvamises pärast Inglise-Saksa mereväe-kokkuleppe sõlmimist peaaegu mingeid lahkarvamisi küsimuses, millised on selle kokkuleppe tagajärjed Balti mere ja Balti riikide suhtes. Rõhuv enamik ajakirjandusest jỗudis järeldusele, et Inglise-Saksa sobing loob mitte üksnes eeldused Saksamaa ülevõimuks Balti merel, vaid tähendab ka vahetut ja tõsist ohtu Balti riikide sõltumatusele.

Nii rōhutas prantsuse ajaleht „Le Temps” korduvalt, et pärast IngliseSaksa kokkuleppe sõlmimist on Saksamaal Balti merel vabad käed. Ajaleht kirjutas 16. juulil 1935, et Balti riikidel on kahtlemata väga tähtis osa Saksamaa kavatsustes ${ }^{25}$.

24 "The Times",

June

14, 1935:

have already

expressed themselves

as

25 ENSV ORKA, f. 957, nim. 1, toim. 698, 1. 232. 
Inglise-Saksa plaanidest Balti mere basseini suhtes ei teinud erilist saladust ka Londoni „Times”, kes toetas 18. juuni kokkulepet. 6. juuli numbris tõi „Times” ära Skandinaavia ajalehtede ärevad avaldused selles küsimuses ning nõustus nende järeldustega. Samas sõnumis ajaleht nagu ütleks Saksamaale ette, mida viimane peaks Baltikumis järgnevalt ette võtma. „Times” märgib, et ükski riik ei saaks teostada kontrolli Balti mere üle ilma samaaegse kontrollita Taani väinade üle ning ilma mereväebaasita Gotlandi saarel või Ahvenamaal. Inglise monopolide häälekandja puudutab vastumeelselt küsimust mereväe-kokkuleppe tagajärgedest Balti basseini riikidele. Kuid isegi tema ei saa jätta märkimata, et „Soomes on Saksamaa merejõu taassünd julgustuseks vastutustundetuile natsionalistlikele elementidele, kes ... otsivad Venemaal seaduslikku tegevusvälja ekspansiooniks" ${ }^{26}$. Mõistagi käis see mitte üksnes Soome, vaid ka kõigi Balti riikide kohta.

Märksa selgemalt väljendus inglise ajakiri „New Statesman and Nation", kes kirjutas, et Saksamaa nõusolek suhtega 35:100, ,oli dikteeritud tema arusaamisest, et see relvastumisnorm on enam kui küllaldane Balti mere muutmiseks Saksa järveks, samuti ka arusaamisest, et kokkulepe on saavutatud Inglismaa vaikival nõusolekul Saksa ekspansionistlike püüdluste teostamisega, mis on suunatud NSV Liidu ja Balti riikide vastu" 27 .

Berliinis võeti teadaanne Inglise-Saksa mereväe-kokkuleppe sõlmimisest vastu suure rõõmuga ning tõlgitseti seda kokkulepet kui akti, mis annab Saksamaale tegevusvabaduse Baltikumis. Peale saksa fašistliku ajakirjanduse seisukohtade selles küsimuses pakub huvi ka Eesti salaluureagendi ettekanne Berliinist, mis jutustab kurikuulsa Alfred Rosenbergi juures korraldatud olengust, millega tähistati mereväe-kokkuleppe sôlmimist ja ,joodi Hitleri esimese tähtsama välispoliitilise programmi sammu liike" 28, Agendi sõnade järgi räägiti sellel õhtul avalikult Baltimaade eelseisvast jaotamisest Saksamaa ja Poola vahel, kusjuures see pidi toimuma Inglismaa täielikul nõusolekul, sest ,.India saatus ja huvid Hiinas on talle tähtsamad kui tühine Baltimere rand”. Rosenbergi arvates oli nüüd tähtis aidata Balti riikides võimule saksasõbralikud valitsused, kes siis ise paluksid Saksamaalt „abi”. Ta kinnitas oma külalistele korduvalt, et nüüdsest peale ei tee Inglismaa Saksamaale Baltikumis takistusi.

Eestis nagu teisteski Balti merd ümbritsevates riikides kutsus IngliseSaksa kokkulepe esile. tugeva rahutuse laiades rahvakihtides. Isegi kodanlikes ringkondades tunnistati, et maad ähvardab kõige tõsisem oht. Nii pühendas kaubandus- ja tööstusringkondade häälekandja „Päevaleht” mereväe-kokkuleppele mitu artiklit, milledes näidati Saksa hegemoonia ohtu Baltikumis ning märgiti, et see akt võib viia sõjani Saksamaa ja NSV Liidu vahel, kusjuures sõjakeerisesse satuvad ka Balti riigid. Ajaleht ei teinud järeldust Ida-Euroopa kollektiivse julgeoleku süsteemi loomise vajaduse kohta, vaid pööras oma paluva pilgu lääneriikide poole, soovitades kokku kutsuda rahvusvaheline konverents Balti mere statuudi kindlaksmääramiseks ning tema kuulutamiseks nn. „lahtiseks mereks”, kuhu ka sõia ajal võiksid sisse pääseda väljaspool Balti mere basseini asetsevate riikide laevastikud ${ }^{29}$. Muidugi ei leidnud see plaan eesti kodanluse seniste hooldajate - Inglise ja Ameerika imperialistide - juures mingit vastukaja ning jäi hüüdjaks hääleks kõrbes.

Tsiteeritud „Pravda” järgi (nr. 196, 18. juuli 1935)

28 ENSV ORKA, f. 957, nim. 14, toim. 10, 1. 71--73b.

29 ,.Päevaleht” nr. 175, 27. juunist ja nr. 184, 6. juulist 1935. 
Uks kodanluse silmapaistvaid liidreid, endine riigivanem Tõnisson, tunnistas samuti, et mereväe-kokkuleppel võib olla Eestile „saatuslik tähendus”. Ajalehe „Postimees” juhtkirjas kirjutas Tõnisson, et „meile tähendab Inglise-Saksa merekokkulepe Saksa sõjalaevastiku mõjulepääsu Balti merel” ja lisas, et „Balti merel manööverdavate Saksa sõjalaevade suits ... võib Balti mere idarannikul muutuda lämmatavaks" 30 .

Olukorra tõsidust oli sunnitud tunnistama ka poolametlik „Kaja”, kelle hinnangu kohaselt Inglise-Saksa kokkulepe oli ,,järsk pööre Euroopa poliitikas" 31 .

Eesti valitsuse ametlikud esindajad aga vaikisid. Neil polnud midagi öelda: tunnistada tegelikku ohtu hitlerliku Saksamaa poolt oleks tähendanud esile kutsuda Berliini viha; täiesti ilmsete faktide eitamine rahutuks muutunud avalikkuse ees oli samuti võimatu - see oleks rahva hulgas kindlasti esile kutsunud pahameeletormi. Alles aasta hiljem kogus sôjavägede ülemjuhataja Laidoner julgust ja avaldas Inglise-Saksa kokkuleppe kohta oma „,autoriteetse" arvamise. See arvamine oli küll järsus vastuolus maa avaliku arvamisega, kuid see-eest oli ta täies kooskõlas kindrali üldiste Nõukogude-vastaste seisukohtadega. „Saksa sõjalaevastiku arenemine pole aga Eestile kartuse põhjuseks," deklareeris Laidoner. "Sõjalaevad Kielis on vastukaaluks sõjalaevadele Kroonlinnas" 32 .

Eesti valitsejad ei mõelnudki sellele, et organiseerida eesti rahva rahvuslike huvide kaitsmist fašistliku Saksamaa poolt ähvardava ohu vastu. Neile tegi muret miski muu - kuidas uute peremeeste juures säilitada om? eesõigused ja võim, olgugi marionetlik võim, ning kuidas veenda sakslasi, et neil pole tarvis Eestis otsida erilist „saksasõbralikku elementi”, kellele võim üle anda, sest Pätsi-Laidoneri klikk on valmis saksa fašismi kõigest hingest teenima ning oskab seda teha teistest paremini.

Sakslaste veenmise eesmärgil saadeti Saksamaale silmapaistev kodanlik diplomaat ja jurist, endine välisminister professor Piip. Temale tehti ülesandeks pidada Saksamaal rida loenguid Eestis pärast 1934. aasta 12. märtsi loodud režiimi kohta ning võita Pätsi-Laidoneri diktatuurile hitlerlaste poolehoid.

Eesti valitseva kliki saadik pidaski 25 . juunil 1935 . aastal loengu Berliini „Ida-Euroopa Uurimise Uhingus”. Nagu nähtub Berliinis asuva Eesti saatkonna ettekandest ${ }^{33}$, samuti ka loengu tekstist, mis anti välja saksakeelse eribrošüürina ${ }^{34}$, ổigustas Piip igati Pätsi diktatuuri ning vabandas teda kõigiti hitlerlike agentide - vapside - kõrvaldamise pärast. Ta kinnitas oma kuulajaile - kuulajaskonna moodustasid aga hitlerliku ladviku esindajad, - et noorte ja vilumata meestena ei oleks vapsid maa autoritaarse valitsemise ülesandega toime tulnud, ning ülistas Pätsi režiimi teeneid sel alal. Pidades meeles oma kuulumist „demokraatliku opositsiooni” ridadesse, püüdis Piip häbelikult iseloomustada Eestis kehtivat režiimi kui „,parlamendist sõltumatut, kuid ka mitte õieti autoritaarset valitsust”. Kõnelejat parandasid aga kohe fašismi küsimustes vilunumad kuulajad. Endine Saksa välisminister Curtius, kes juhatas koosolekut, märkis sõbralikult, et „,kuigi kõneleja on praegust Eesti režiimi nimetanud vaid „,quasi”-autoritaarseks ülemineku korraks, omab Eesti siiski kõiki autoritaarse riigi tunnuseid...,"35.

${ }^{30}$ „Postimees” nr. 178, 4. juulist 1935. Vrd. „Pravda” nr. 194, 16. juulist 1935.

31 "Kaja” nr. 146, 24. juunist 1935.

32 ENSV ORKA, f. 957, nim. 1, toim. $715,1.203$.

33 ENSV ORKA, f. 957, nim. 14, toim. 169, 1. 16-35.

34 A. P i i p. Estlands Weg zur neuen Verfassung, Tartu, 1936.

35 ENSV ORKA, f. 957, nim. 14, toim. 169, 1. 16. 
Varsti pärast Inglise-Saksa mereväe-kokkuleppe sõlmimist tehti teatavaks Saksamaa sốjalaevastiku ehitamise plaan 1935 . aastaks ${ }^{36}$. Selle programmi mõned iseloomulikud jooned kinnitasid oletust, et nüüdsest peale keskendas Hitleri valitsus oma peamised jõupingutused Balti mere „omandamisele". Tähelepanu äratab asjaolu, et suur enamik ehitamisele tulevatest allveelaevadest (20 üldarvust 28 ) kuulus väikeste allveelaevade klassi (veeväljasurve $250 \mathrm{t}$ ). Säärased allveelaevad olid määratud operatsioonideks vôrdlemisi madala veega ja tugevasti liigestatud rannajoonega meredes, nagu seda on Balti meri. Saksa sõjalaevastik täienes suure arvu miinilaevade ja -traaleritega ning kiires korras loodi suuri torpeedokaatrite üksusi ${ }^{37}$.

Saksa sõjalaevastik, mis varem end Soome lahes peaaegu ei näidanud, asus selle meretandriga ning sellega külgnevate Eesti ja Soome baasidega aktiivselt tutvuma. Soome skäärid on ideaalseks tegevusrajooniks just niisugustele väikestele allveelaevadēele, torpeedokaatritele jne., mida Saksa laevaehitustehased suurel hulgal valmistasid. Samal ajal võeti arvele Soome territooriumil paiknevad lennuväljad ning kavatseti uute ehitamist. Nagu märkis „Pravda”, polnud Soome lennuväele säärast laialdast aerodroomide ehitamist tarvis - siin valmistati ette baasi palju võimsama lennuväe, nimelt Saksa lennuväe jaoks. „Soome lahe meretandri omandamine,” kirjutas „,Pravda”, ,kuulub nähtavasti ühe koostisosana plaani, mille järgi saksa imperialism valmistab ette sõda idas" 38 .

1936. aastaks viidi Saksamaal läbi mõned tähtsad muudatused laevastiku juhatamise süsteemis. Ohtlasi muudeti Balti mere suudmes asetsev Kieli sadam Saksa laevastiku peabaasiks, Wilhelmshaven aga, mis omal ajal oli Saksa ,avamere laevastiku” peabaasiks, muutus teisejärguliseks baasiks. See on samuti tõendiks selle kohta, et fašistlik Saksamaa pöördus „näoga Balti mere poole" 39 .

Saksa diplomaatia tegi pingutusi, et sõjalis-strateegilisi samme Balti merel kroonida NSV Liidu vastu suunatud erilise merepakti sõlmimisega Saksamaa, Poola ja Soome vahel. Just sel eesmärgil külastas Poola välisminister Beck 1935. aasta augustis Helsingit ${ }^{40}$. Eestit nagu ka Lätit ja Leedut tahtsid saksa fašistlikud diplomaadid selle süsteemiga siduda nn. „suure Balti liidu” kaudu, mille loomisele nüüd asuti kahekordse innuga.

Erilist huvi pakub Inglise diplomaatia kaasabi suure Nõukogude-vastase bloki kokkuklopsimiseks Balti riikidest Poola juhtimisel ning selle bloki allutamiseks hitlerlikule Saksamaale. Kui Briti diplomaatia veel 1934. aastal töötas vastu säärastele plaanidele, siis nüüd, pärast merevåe-kokkuleppe sõlmimist Saksamaaga, muutis Inglismaa selles küsimuses järsult oma seisukohta, tehes seda, tõsi küll, avalikkuse eest varjatult. Nii kirjutas Eesti saadik Varssavis Markus oma välisministrile 5. juulil 1935. aastal, et Suurbritannia ja Prantsusmaa suursaadikud avaldasid tema ees lootust, et Eestil õnnestub Leedut Poolaga lepitada. Selgub, et Inglise diplomaatia oli välja töötanud isegi teatava tegevusprogrammi, mille eesmärgiks oli Leedu ja Poola lepitamine ning nende ühendamine ,,suure Balti liidu” koosseisus. Inglise suursaadik soovitas Eestil teha ettepanek Poolale selle kohta, et võetaks tarvitusele „mõni eriline majandusline käitumine leedulastega Vilno rajoonis, olgu see näit. Vilno rajoonile laiendatud piiririba

36 «Правда» № 188 от 10 июля 1935 г.

37 «Правда» № 180 от 2 июля 1935 г.

38 «Правда» № 180 от 2 июля 1935 г.

39 Л. Ив а нов, Морское соперничество империалистических держав, М.-Л., 1936, стр. 183.

40 «Правда» № 221 от 12 августа и № 224 от 15 августа 1935 r. 
soodustused või mõnel muul teel". Briti diplomaat kinnitas Eesti saadikule, et Inglismaa tervitaks väga ja toetaks säärast Eesti sammu ${ }^{41}$.

Inglise valitsevate ringkondade kaasabi Hitleri ekspansiooniplaanidele Baltikumis leidis eriti kujuka väljenduse selles uues, ennenägematus viisis, kuidas Inglise välisministeerium reageeris natside avameelsetele väljendustele nende plaanide kohta Baltikumis, samuti ka nende plaanide teostamiseks astutud praktilistele sammudele.

1935. aasta oktoobris selgitas Saksa sõjamajanduse juht, Riigipanga direktor Schacht Hitleri kliki agressiivseid plaane. Jutuajamisel Rahvusvahelise Arvelduspanga peadirektori Montague Normaniga ja Prantsuse Panga direktori Tannery'ga, mis leidis aset emissioonipankade direktorite nõupidamisel Baselis, ütles Schacht, et Saksamaal pole mingeid agressiivseid eesmärke läänes, kuna Saksa ekspansioon suunatakse itta, kôigepealt Balti riikide vastu, siis aga Ukraina vastu, mida Saksamaa võiks jagada Poolaga ${ }^{42}$.

Seda silmapaistva hitlerlase avaldust hinnati välismaa ajakirjanduses üksmeelselt kui ümberlükkamatut tunnistust Saksamaa agressiivsetest kavatsustest Balti riikide suhtes. Isegi reaktsiooniline inglise ajaleht „Observer” kirjutas sel puhul: „Saksamaa praegune soov saavutada häid vahekordi Lääne-Euroopaga on tingitud tema vahenditust koondumisest ülesannetele Ida-Euroopas ... Saksa diplomaatia lähema ekspansiooni plaan on sihitud Balti riikide, Poola ja Vene suunas" ${ }^{43}$.

Ometi teatati Foreign Office'is Eesti saadikule, et Schachti avaldused võib lihtsalt panna ad acta, sest ,neil võib praegu olla ainult akadeemiline tähtsus" ${ }^{44}$. Iseloomulik on samuti ka see, et tervelt kuu aega pärast Schachti läbirääkimisi Baselis Inglise välisministeeriumi põhjamaade osakonna juhataja Collier ,oli alles äsja saanud vaid puudulikku informatsiooni" selles küsimuses ${ }^{45}$.

Niisugused on üksikud näited sellest, kuidas imperialistlike lääneriikide diplomaatia kohe pärast Inglise-Saksa mereväe-kokkuleppe teokssaamist asus soosima ja abistama Saksa ekspansiooni Balti mere idarannikul, NSV Liidu loodeosa eluliste keskuste lähistel. Järgnevail aastail viis see poliitika nii kaugele, et välismaisest imperialismist sõltuva kodanliku Eesti nagu ka teiste Balti riikide - majandus ja poliitika allutati järk-järgult fašistliku Saksamaa agressiivsele Nõukogude-vastasele poliitikale. Seega viidi eesti rahvas rahvusliku katastroofi ning otsese hävingu ohtu, millest ta pääses Teise maailmasõja alguses tänu Nõukogude Liidu vankumatule rahu ja väikerahvaste sõltumatuse kaitsmise poliitikale ja eesti töölisklassi ennastsalgavale võitlusele.

NLKP Keskkomitee juures asuv

Ohiskonnateaduste Akadeemia

Saabus toimetusse

3. I 1955

41 Varssavis asuva Eesti saadiku kiri välisministrile 5. juulist 1935. ENSV ORKA, f. 957, nim. 14, toim. 176, 1. 10-13.

42 Vt. "Pravda” nr. 305, 4. novembrist 1935, samuti ka R. P a $1 \mathrm{me}$ D ut t'i raamat World Politics 1918-1936, New York, 1936, p. 294.

43 Tsiteeritud Londonis asuva Eesti saadiku kirja järgi 11. novembrist 1935. ENSV ORKA, f. 957 , nim.-14, toim. 175, 1. $44-45$.

44 Londonis asuva Eesti saadiku ettekanne 26. novembrist 1935. ENSV ORKA, f. 957, nim. 14 , toim. $175,1.55$.

45 Londonis asuva Eesti saadiku ettekanne 15. novembrist 1935. ENSV ORKA, f. 957 , nim. 14 , toim. $175,1.47$. 


\title{
ОБ АНГЛО-ГЕРМАНСКОМ ИМПЕРИАЛИСТИЧЕСКОМ СГОВОРЕ ПО ВОПРОСУ О БАЛТИЙСКОМ МОРЕ И ПРИБАЛТИКЕ (1935 ГОД)
}

\author{
М. А. ПЕСТИ
}

Резюме

В результате мирового экономического кризиса 1929-1933 годов еще более усилилась экономическая и политическая зависимость буржуазной Эстонии от империалистических держав. В связи с приходом Гитлера к власти в Германии и возобновлением открыто экспансионистской политики германского империализма обострилась борьба за рынки Прибалтики, особенно между монополиями Англии и Германии. В этой борьбе Англия имела определенный перевес. В 1933-1934 гг. она ревниво охраняла свое первое место во внешнеторговом обороте прибалтийских стран, как при помощи особого «экспортного наступления» на Прибалтику, так и путем политического давления. Великобритания добилась в 1934 году заключения весьма выгодных для нее торговых договоров с Әстонией, Латвией и Литвой.

Однако острая борьба между двумя империалистическими державами за экономическое и военно-политическое господство на восточном берегу Балтики не исключала обоюдных поисков компромисса. Основой для таких поисков служили антисоветские устремления, одинаково свойственные как германским, так и англо-американским империалистам, и их стремление к «мирному» разделу между собой сфер влияния и сфер приложения капиталов. Еще в 1934 году до руководителей эстонского правительства доходили сведения о том, что влиятельные круги в Англии готовы в общем плане сближения с гитлеровской Германией пойти на значительное усиление германского влияния в прибалтийских государствах. В английской буржуазной прессе с осени 1934 года началась пропаганда отказа Великобритании от своих «интересов» в Прибалтике.

В первой половине 1935 года все настойчивее стали распространяться слухи о предстоящем сговоре между Англией и Германией по балтийскому вопросу. Как сообщил министр иностранных дел Эстонии в одном из своих докладов главе государства, «фюрер» эстонских немцев получил в Берлине даже особые инструкции относительно действий гитлеровской агентуры в Эстонии в связи с переходом Эстонии и других прибалтийских стран в сферу влияния Германии.

В тот же период англо-американская дипломатия начала проявлять усиленную «заботу» об обеспечении независимости прибалтийских государств от ... Советского Союза, который неустанно выступал за создание системы коллективной безопасности на востоке Европы, в защиту народов Прибалтики от империалистической агрессии со стороны Германии. Официальные представители США и Англии подстрекали эстонских деятелей на антисоветские выступления.

Британская дипломатия теперь оказывала нажим на Литву с целью добиться уступок с ее стороны в пользу гитлеровских агрессоров по вопросу о клайпедской области, а также содействовала попыткам эстонских правителей «примирить» Литву с Польшей. И то и другое могло лишь облегчить агрессивные действия фашистской Германии в Прибалтике и во всей Восточной Европе. Высокопоставленный чиновник Форин оффиса Колльер весной 1935 г. проповедовал «необходимость» заключения пактов о ненападении между гитлеровской Германией и прибалтийскими государствами. 
Так происходила расчистка пути к англо-германскому соглашению по балтийскому вопросу. Соглашение это было выработано в ходе переговоров между представителями правительств Великобритании и гитлеровской Германии, имевших место весной 1935 года, после расторжения Гитлером военных статей Версальского договора и начала открытого перевооружения Германии для новой войны. В период этих англо-германских переговоров в Англии резко усилилась пропаганда «невмешательства» в прибалтийские дела. Қак докладывали эстонские дипломатические представители из Лондона, там заговорили о том, что прибалтийские государства «находятся в опасной зоне», и курсы эстонских ценных бумаг на Лондонской бирже начали падать. Английская буржуазная печать все более откровенно распространялась о «неизбежности» «общего изменения положения в Восточной Европе», которое должно было «включать в себя» как статут литовской области Клайпеды, так и «много других дел».

Зная о сокровенном желании империалистов США и Англии столкнуть Германию с Советским Союзом, главари гитлеровской шайки спекулировали на этом и в беседах с англо-американскими деятелями всячески расписывали свои агрессивные замыслы относительно Балтийского бассейна, находящегося на подступах к Ленинграду: Некоторые из подобных откровений гитлеровцев проникли даже на страницы опубликованных мемуаров буржуазных дипломатов, таких, как бывший американский посол в Берлине У. Додл.

Англо-германский сговор по вопросу о Балтийском море и Прибалтике был окончательно оформлен известным морским соглашением, заключенным между Великобританией и гитлеровской Германией 18 июня 1935 года. Это сепаратное соглашение, грубо нарушившее условия Версальского мирного договора, предоставило Германии практически неограниченные возможности для увеличения ее военно-морского флота. В мировой капиталистической прессе не было двух мнений относительно того, что этот сговор означал установление германской гегемонии на Балтийском море. Что же касается судьбы прибалтийских государств, то даже большинство буржуазных органов печати западных стран вынуждено было в той или иной форме признать, что англо-германское морское соглашение означает молчаливое согласие правящих кругов Великобритании на осуществление экспансионистских устремлений германских фашистов в Прибалтике.

В Эстонии, как и в других странах Балтийского бассейна, англо-германский сговор вызвал сильную тревогу в широких слоях населения. Серьезнейшую опасность, нависшую над страной, признавали и некоторые буржуазные круги.

Представители правящей в стране фашистской клики Пятса-Лайдонера также правильно поняли смысл англо-германских переговоров и сговора. Они теперь попали в несколько неудобное положение, так как проанглийская клика Пятса-Лайдонера в свое время пришла к власти, насильственно устранив с пути гитлеровскую агентуру в Эстонии - клику так называемых вапсов. Но правители Эстонии не пали духом. Буквально на другой же день после англо-германских переговоров 1935 года они отправили в Берлин в качестве доверенного лица бывшего министра иностранных дел Эстонии Пийпа, который пытался завоевать клике ПятсаЛайдонера расположение гитлеровской верхушки и убедить ее в том, что тогдашние правители Эстонии лучше любых других смогут служить германскому фашизму. Стремясь задобрить гитлеровцев, главнокомандующий эстонской армией Лайдонер наперекор общественному мнению страны заявил, будто германское военно-морское строительство «не является источником опасений для Эстонии», и провокационно добавил: 
«Военные корабли, находящиеся в Киле, являются противовесом для военных кораблей в Кронштадте».

Таким образом, фашистские правители Эстонии и не помышляли о том, чтобы организовать защиту национальных интересов эстонского народа перед лицом прямой угрозы со стороны гитлеровской Германии. Они были озабочены другим - тем, как бы задобрить новых империалистических хозяев Әстонии и завоевать их полное доверие.

Вскоре после заключения англо-германского морского соглашения было объявлено о программе военно-морского строительства Германии на 1935 год. Некоторые характерные черты этой программы подтвердили предположение о том, что отныне гитлеровское правительство свои главные усилия на море сосредоточивало на «освоение» Балтийского моря. Германский флот, ранее почти не показывавшийся в Финском заливе, приступил к активному изучению этого будущего морского театра военных действий и прилегающих к нему финских и эстонских баз. В Финляндии началась деятельная подготовка к строительству развернутой сети аэродромов для германской авиации.

Германская дипломатия прилагала усилия к тому, чтобы увенчать военно-стратегические мероприятия Германии на Балтике заключением особого морского пакта между Германией, Польшей и Финляндией, направленного против СССР. Әстонию, как и Латвию и Литву, гитлеровцы предполагали связать с этой системой посредством так называемого «большого прибалтийского союза», который охватил бы, кроме трех прибалтийских государств, также Польшу и Финляндию. Английская дипломатия, которая еще в 1934 году противодействовала осуществлению подобных планов, теперь, после сговора с гитлеровской Германией, выражала свое полное одобрение подобным планам и способствовала попыткам Польши и Эстонии сколотить этот антисоветский блок под верховенством гитлеровской Германии.

Англо-американская политика направления гитлеровской агрессии против СССР и перераспределения сфер влияния в районе Балтийского моря, выражением которой явилось англо-германское морское соглашение 1935 года, и готовность продажной клики правителей буржуазной Эстонии служить любому империалистическому хозяину привели к тому, что в последующие годы экономика и политика буржуазной Әстонии были подчинены целям и задачам антисоветской агрессивной политики гитлеровцев. Над эстонским народом нависла угроза национальной катастрофы и физического истребления в германо-фашистском пекле.

Только политика защиты мира и независимости малых народов, неуклонно проводимая Советским Союзом, и героическая борьба эстонского рабочего класса спасли Эстонию от национальной катастрофы. Эстония в 1940 году вырвалась из лагеря империализма и вошла в состав CCCP.

Академия общественных наук при ЦК КПСС

Поступила в редакцию 3 I 1955 